\title{
USULAN KERANGKA STANDAR KURSI RODA MANUAL SEBAGAI ACUAN PENYUSUNAN STANDAR NASIONAL INDONESIA (SNI)
}

\section{Manual Wheelcahirs Standards Framework as a Reference for Indonesia National Standard (SNI)}

\author{
Rizki Amalia Pratiwi' ${ }^{1}$ Fakhrina Fahma1, Wahyudi Sutopo ${ }^{1}$, Eko Pujiyanto ${ }^{1}$, Suprapto², Meilinda \\ Ayundyahrini² \\ ${ }^{1}$ Proram Studi Teknik Industri, Universitas Sebelas Maret \\ Gedung 1 Fakultas Teknik, JI. Ir. Sutami No.36A, Surakarta, Indonesia \\ ${ }^{2}$ Pusat Penelitian dan Pengembangan Standardisasi, Badan Standardisasi Nasional \\ Gedung I BPPT Lantai 12, Jalan M.H. Thamrin No. 8, Jakarta \\ e-mail: kikiamalia29@gmail.com
}

Diterima: 13 September 2018, Direvisi: 19 November 2018, Disetujui: 26 November 2018

\begin{abstract}
Abstrak
Teknologi alat kesehatan berkembang sangat pesat, pemerintah terus berupaya untuk mendorong berkembangnya industri alat kesehatan, salah satunya kursi roda. Sebagai upaya mengembangkan industri alat kesehatan, pemerintah juga merekomendasikan pergembangan SNI alat kesehatan. Indonesia memiliki SNI 094663-1998 kursi roda, namun sudah berusia 20 tahun dan belum pernah mengalami pembaruan, untuk itu diperlukan kaji ulang standar kursi roda, agar dapat harmonis dengan perkembangan teknologi saat ini. Artikel ini menggunakan pendekatan FACTS (Framework for Analysis Comparison and Testing Standard). Terdapat 4 tahap pada pendekatan FACTS, yaitu analisis stakeholder, analisis teknis, perbandingan standar, dan pengujian standar. Pada tahap pengujian standar, digunakan SEM (Structural Equation Model), kerangka SEM digunakan untuk memverifikasi bahwa kerangka standar yang dikembangkan dapat mencapai tujuan standardisasi. Dari pendekatan FACTS pada artikel ini didapatkan kerangka standar yang dapat digunakan untuk penyusunan standar kursi roda dan metode verifikasinya. Dihasilkan 8 parameter standar yang diusulkan menjadi Acuan RSNI, yaitu stabilitas stastis, kemampuan manuver, dimensi, keefektifan rem, ketahanan pengapian, kekuatan statis, kekuatan impact, dan kekuatan fatigue.
\end{abstract}

Kata kunci: Standar Nasional Indonesia (SNI), Kursi roda manual, FACTS, SEM

Abstract

Medical device technology growing rapidly, the government also try to develop the medical devices industry, one of them is wheelchairs. As the way to develop the medical device industry, government also concern to develop Indonesian Nation Standard of medical devices. Indonesia has SNI 09-4663-1998 about wheelchairs, but it has been for 20 years and never be renewal, a wheelchai because of this review for wheelchairs standard is needed, so the standard can be in harmony with current technological developments. This study uses the FACTS approach (Framework for Analysis Comparison and Testing Standard). There are 4 stages in FACTS approach consist of stakeholder analysis, technical analysis, comparison standard, and testing standards. At the testing standard stage SEM (Structural Equation Model) are used, SEM is used to establish that standards can achieve the objectives of standardization. From the FACTS approach in this study, obtained standards framework that can be used to regulate the wheelchairs, and the verification method for standard. There are 8 standard parameters that will be developed into manual wheelchair RSNI, namely stability, maneuverability, dimensions, brake effectiveness, ignition level, static strength, impact strength, and fatigue strength.

Keyword: Indonesia National Standard (SNI), Manual wheelchairs, FACTS, SEM

\section{PENDAHULUAN}

Teknologi alat kesehatan berkembang sangat pesat seiring dengan perkembangan teknologi informasi (Kementerian Kesehatan, 2015). Pemerintah juga terus berupaya mendorong untuk berkembangnya industri alat kesehatan untuk memacu daya saing nasional (Kementerian Perindustrian, 2015). Saat ini sebanyak 65 produsen di dalam negeri telah mampu memproduksi alat kesehatan, salah satu yang mampu di produksi adalah kursi roda (Kementerian Perindustrian, 2015). Kursi roda adalah alat bantu yang paling banyak digunakan 
untuk meningkatkan mobilitas pribadi para penyandang cacat.

Sebagai upaya pengembangan industri alat kesehatan, pemerintah juga merekomendasikan pengembangan Standar Nasional Indonesia (SNI) melalui peningkatan jumlah SNI Alat Kesehatan dan laboratorium pengujian (Kementrian Perindustrian, 2015). Pada saat ini Indonesia telah memiliki SNI tentang kursi roda, yaitu SNI 09-4663-1998, SNI kursi roda ini telah ditetapkan sejak tahun 1998 dan telah digunakan selama 20 tahun tanpa adanya pembaharuan. Padahal perkembangan teknologi kursi roda mengalami transformasi yang cepat, para pengembang kursi roda mulai menerapkan teknologi pada kursi roda yang dibuatnya (Kharisma, 2016). Oleh sebab itu diperlukan kaji ulang terhadap standar yang telah ada. Sehingga dengan adanya pengembangan SNI kursi roda diharapkan mampu mengakomodasi perkembangan teknologi sert harmonis dengan perkembangan standar yang ada.

Pentingnya pengembangan standar disebabkan oleh acuan standar yang diberlakukan oleh pemerintah akan mendorong pelaku usaha untuk mengembangkan produknya sesuai dengan standar yang ditetapkan, dan memudahkan dalam proses pengembangan produk. Proses pengembangan standar baru memiliki masalah di awal proses pengembangan, khususnya untuk mengidentifikasi langkah apa yang diperlukan untuk mengembangkan yang baru standar. Sehingga digunakan pendekatan FACTS (Framework for Analysis, Comparison, and Testing of Standard) untuk melakukan pengembangan standar (Prianjani, 2017).

\section{TINJAUAN PUSTAKA}

\subsection{Standar dan Standardisasi}

Standar adalah spesifikasi teknis atau sesuatu yang dibakukan termasuk tata cara dan metode yang disusun berdasarkan consensus semua pihak yang terkait dengan memperhatikan syaratsyarat keselamatan, keamanan, kesehatan, lingkungan hidup, perkembangan ilmu pengetahuan dan teknologi, serta pengalaman, perkembangan masa kini dan masa yang akan datang untuk memperoleh manfaat yang sebesarbesarnya (PP No. 102 Tahun 2000).

Untuk merumuskan standar, perlu dilakukan standardisasi. Proses standardisasi yaitu proses merumuskan, menetapkan, menerapkan dan merevisi standar, yang dilaksanakan secara tertib melalui kerjasama dengan semua pihak yang berkepentingan (Badan Standar Nasional, 2009). Dalam UU No. 20 Tahun 2014, standardisasi didefinisikan sebagai proses merencanakan, merumuskan, menetapkan, menerapkan, memberlakukan, memelihara, dan mengawasi standar yang dilakukan secara tertib dan bekerja sama dengan semua pemangku kepentingan.

\subsection{Kursi Roda Manual}

Kursi roda merupakan salah satu alat bantu bagi penyandang cacat kaki untuk dapat berpindah dari satu tempat ke tempat lain, baik di tempat datar maupun dari tempat rendah ke tempat yang lebih tinggi. Kursi roda juga digunakan untuk meningkatkan kemampuan mobilitas bagi orang yang memiliki kekurangan seperti: orang yang cacat fisik, pasien rumah sakit, orang tua (manula), dan orang-orang yang memiliki resiko tinggi untuk terluka, bila berjalan sendiri (Batan, 2006). Secara umum, kursi roda dibagi menjadi 2 (dua) jenis, yaitu kursi roda manual (conventional wheelchair) dan kursi roda berpenggerak motor (motor powered wheelchair). Gambar kursi roda manual beserta bagian-bagiannya, ditunjukkan pada Gambar 1.

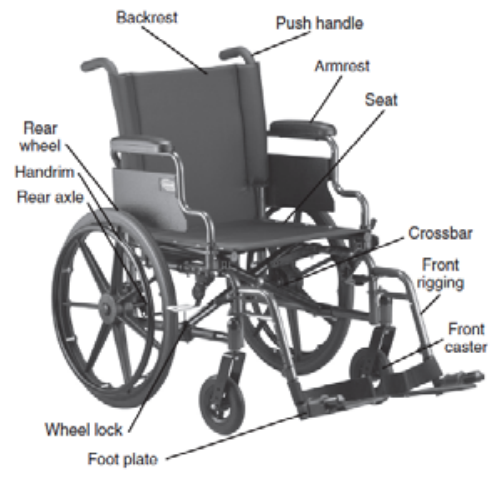

Gambar 1 Kursi Roda Manual dan Bagiannya (Cook, 2015).

\subsection{FACTS (Framework for Analysis Comparison and Testing Standard)}

FACTS (A Framework for Analysis, Comparison, and Testing of Standard) adalah metodologi yang dikembangkan oleh NIST (National Institut of Standards and Technology, US Departement of Commerce) yang dapat digunakan untuk mengembangkan dan mengimplementasikan standar (Witherell, 2013). Pendekatan FACTS mempertimbangkan kepentingan seluruh stakeholder terkait, pendekatan ini juga yang menyediakan framework untuk menganalisa, membandingkan dan menguji standar dengan cara strukturisasi dan formalisasi informasi melalui Zachman framework. Zachman Framework merupakan kerangka yang digunakan untuk memeperoleh informasi menggunakan pertanyaan $5 \mathrm{~W} 1 \mathrm{H}$, yaitu: What, How, When, Who, Where, dan Why. 


\subsection{SEM (Structural Equation Model)}

Structural Equation Model (SEM) merupakan model untuk menjelaskan secara menyeluruh hubungan antar variabel yang ada dalam penelitian. SEM digunakan bukan untuk merancang suatu teori, tetapi lebih ditujukan untuk memeriksa dan membenarkan suatu model. Oleh karena itu, syarat utama menggunakan SEM adalah membangun suatu model hipotesis yang terdiri dari model struktural dan model pengukuran dalam bentuk diagram jalur yang berdasarkan justifikasi teori. SEM adalah merupakan sekumpulan teknik-teknik statistik yang memungkinkan pengujian sebuah rangkaian hubungan secara simultan. Hubungan itu dibangun antara satu atau beberapa variabel independen (Santoso, 2011).

Terdapat 2 model matematis dalam SEM, yaitu model pengukuran dan model struktural. Model pengukuran adalah bagian dari model SEM yang menggambarkan hubungan antara variabel laten dengan indikator-indikatornya. Sedangkan model struktural menggambarkan hubungan antar variabel-variabel laten atau antar variabel eksogen dengan variabel laten. Contoh model SEM terdapat pada Gambar 2.

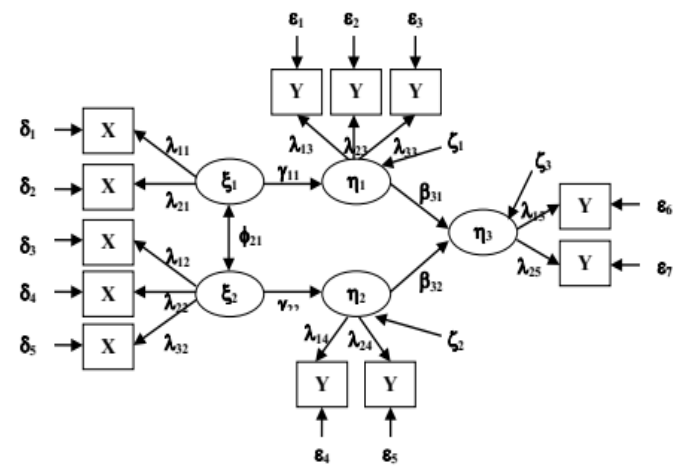

Gambar 2 Contoh Model SEM.

Keterangan:

Elips: konstruk laten (variabel laten); Kotak: variabel manifes (indikator); $\xi$ (ksi): konstruk laten eksogen; $\eta$ (eta): konstruk laten endongen; $Y$ (gama): parameter untuk menggambarkan hubungan langsung variabel eksogen terhadap variabel endogen; $\beta$ (beta): parameter untuk menggambarkan hubungan langsung variabel endogen dengan variabel endogen lainnya; $\zeta$ (zeta): kesalahan struktural (structural error) yang terdapat pada sebuah konstruk endogen; $\delta$ (delta): measurement error yang berhubungan dengan konstruk eksogen; $\varepsilon$ (epsilon): measurement error yang berhubungan dengan konstruk endogen; $\lambda$ (alfa): factor loadings, parameter yang menggambarkan hubungan langsung konstruk eksogen dengan variabel manifesnya; $X$ : variabel manifes yang berhubungan dengan konstruk eksogen; $Y$ : variabel manifes yang berhubungan dengan konstruk endogen (Nurwullan, 2015).

\section{METODE PENELITIAN}

Artikel ini menggunakan pendekatan FACTS atau Framework for Analysis Comparison and Testing Standard. FACTS adalah pendekatan yang dapat digunakan untuk mengembangkan dan mengimplementasikan standar. Pendekatan FACTS ini dapat diaplikasikan pada setiap tahapan siklus hidup standar yaitu: (1) pengembangan standar; (2) implementasi standar; (3) Pemeliharaan standar, dan pendekatan ini dapat diterapkan dalam setiap siklus hidup standar secara terpisah (Witherell, 2013).

Pendekatan FACTS dipilih karena pendekatan ini mempertimbangkan kepentingan seluruh stakeholder terkait dalam pengembangan standar (Rahmawatie, 2017). Konsep FACTS sejalan dengan prinsip konsensus BSN yang mempertimbangkan pendapat atau persyaratan stakeholder yang tidak berpihak pada pihak tertentu untuk mengambil keputusan (Sutopo, 2018). Pendekatan ini juga yang menyediakan Framework untuk menganalisa, membandingkan dan menguji standar dengan cara strukturisasi dan formalisasi informasi melalui Zachman framework. Zachman framework merupakan kerangka yang digunakan untuk memperoleh informasi menggunakan pertanyaan $5 \mathrm{~W} 1 \mathrm{H}$, yaitu: What, How, When, Who, Where, dan Why (Witherell, 2013). Terdapat 4 tahap utama dalam pendekatan FACTS: (1) Analisis Stakeholder, (2) Analisis Teknis, (3) Perbandingan Standar, dan (4) Pengujian Standar. Metode penelitian ditunjukkan pada Gambar 3.

Tahap yang pertama adalah analisis stakeholder, pada tahap ini dilakukan identifikasi stakeholder terkait dengan perancangan standar kursi roda manual, dan identifikasi kebutuhan stakeholder. Tujuan dari tahap ini adalah untuk mengetahui semua kebutuhan dari stakeholder dan parameter apa saja yang digunakan untuk pengembangan standar kursi roda. Analisis stakeholder diawali dengan pembuatan desain kuesioner kebutuhan standar kursi roda. Kuesioner juga bersifat terbuka sehingga stakeholder terkait dapat memberikan masukan mengenai parameter yang belum ditanyakan di dalam kuesioner. 


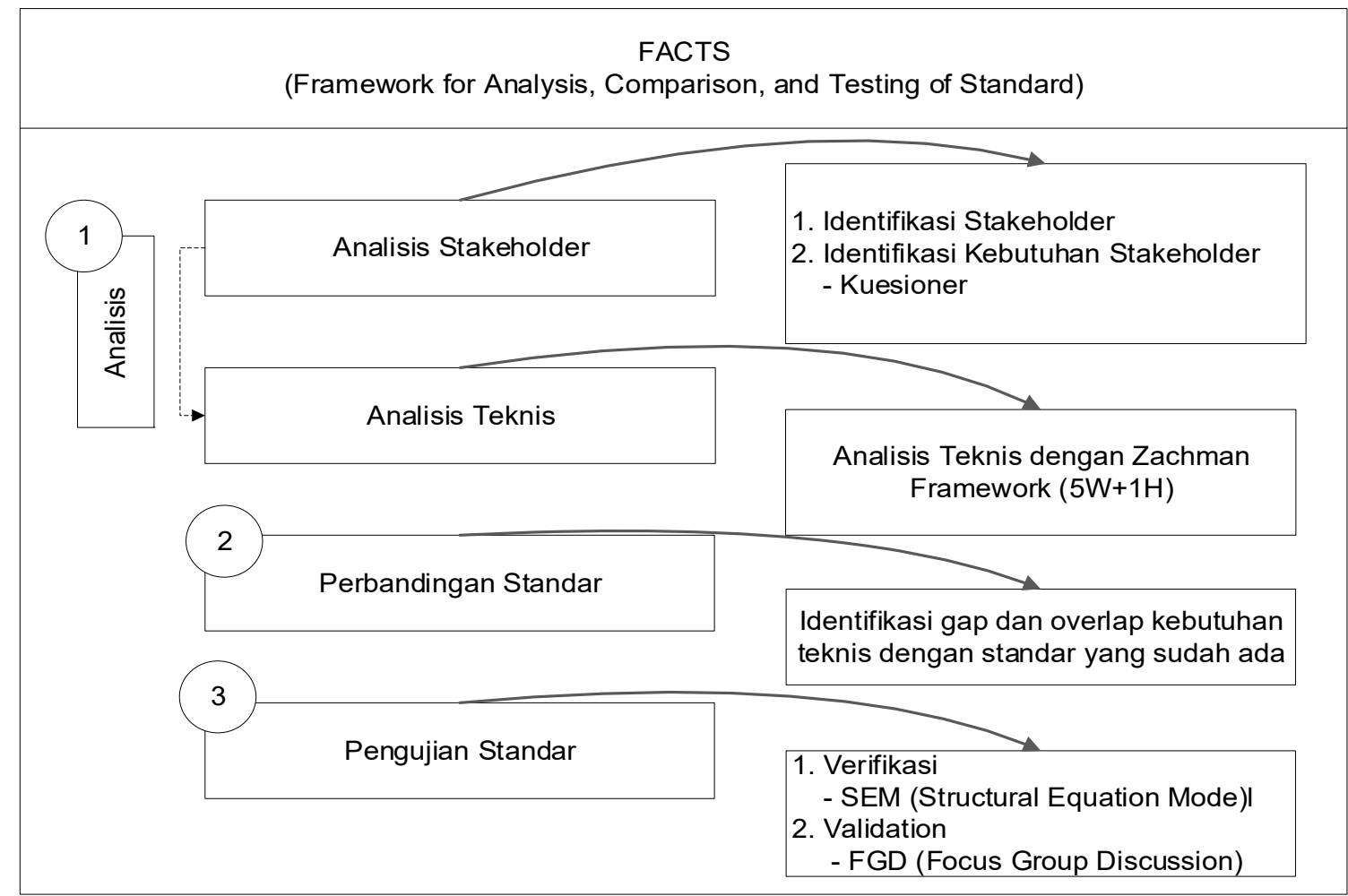

Gambar 3 Metode Penelitian.

Tahap kedua adalah analisis teknis, pada tahap ini kebutuhan stakeholder yang didapatkan pada analisis stakeholder di terjemahkan menjadi kebutuhan teknis kursi roda. Tujuan dari tahap ini adalah untuk memperoleh spesifikasi kebutuhan untuk standar kursi roda. Tahap selanjutnya adalah perbandingan standar, bertujuan untuk mengidentifikasi gap dan overlap antara hasil analisis teknis dengan standar yang telah ada baik standar nasional maupun internasional. Dari hasil ketiga tahap tersebut dapat dihasilkan kerangka untuk standar kursi roda manual.

Tahap yang terakhir adalah tahap pengujian standar, tahap ini bertujuan untuk memastikan bahwa standar yang dikembangkan telah memenuhi seluruh kebutuhan stakeholder dan memastikan bahwa seluruh stakehokder mampu memenuhi persyaratan dan pengujian yang diminta. Terdiri dari verifikasi dan validasi. Pada tahap verifikasi dilakukan suatu pembaharuan dengan digunakannya SEM. SEM adalah alat analisis statistik yang dapat menjelaskan hubungan di antara variabel laten dengan variabel manifes, serta dapat mengetahui pengaruh hubungan antar variabel laten dengan memperhitungkan kesalahan yang akan selalu ada pada setiap perhitungan (Santoso, 2015). Dengan menggunakan SEM dapat diketahui kebutuhan stakeholder yang memiliki pengaruh terhadap tercapainya tujuan standardisasi, sehingga hanya variabel-variabel yang penting saja yang diatur didalam standar. Pada artikel ini variabel laten didapatkan dari kerangka standar dan dihubungkan dengan tujuan standardisasi. Perhitungan SEM dilakukan dengan penyebaran kuesioner, dan diolah menggunakan software Smart-PLS. Kemudian pengujian standar diakhiri dengan validasi yang dilakukan dengan Focus Group Disscussion dengan stakeholder terkait.

\section{HASIL DAN PEMBAHASAN}

\subsection{Analisis Stakeholder}

Tahap pertama yang dilakukan adalah identifikasi stakeholder, karena pada proses pengembangan standar diperlukan partisipasi stakeholder agar standar yang disusun dapat mengakomodasi seluruh kepentingan stakeholder (Whiterell, dkk, 2013). Menurut UU No. 20 tahun 2014, yang dimaksud dengan stakeholder (pemangku kepentingan) adalah pihak yang mempunyai kepentingan terhadap kegiatan standardisasi dan penilaian kesesuaian, yang terdiri atas unsur konsumen, pelaku usaha, asosiasi, pakar, cendekiawan, kementerian, lembaga pemerintah nonkementerian, dan/atau Pemerintah Daerah. Pemilihan stakeholder terkait untuk artikel ini dipilih langsung oleh BSN sebagai pihak yang terkait langsung dengan perumusan standar, stakeholder yang terkait ditujukkan pada Tabel 1. 
Tabel 1 Stakeholder Kursi Roda Terpilih.

\begin{tabular}{ll}
\hline Stakeholder & Keterangan \\
\hline PT. Mega Andalan Kalasan & Produsen Kursi Roda (Pengembang kursi roda) \\
PT. Shima Prima Utama & Produsen Kursi Roda (Pengembang kursi roda) \\
PT. Tesena Inovindo & Produsen Kursi Roda (Pengembang kursi roda) \\
PT. Dharma Medipro & Produsen Kursi Roda (Pengembang kursi roda) \\
PT. Asia Technic Utama & Konsumen Kursi Roda \\
RSUD Yogyakarta & Konsumen Kursi Roda \\
BBRSBD & Konsumen Kursi Roda sekaligus Lembaga Pemerintah \\
RSUD Tangerang Selatan & Konsumen Kursi Roda \\
RSUD Kota Bekasi & Konsumen Kursi Roda \\
RSUD Cempaka Putih & Konsumen Kursi Roda \\
RSUD Kota Depok & Konsumen Kursi Roda \\
Teija Gumilar & Pakar Kursi Roda dari Adam Mickiewicz University Polandia \\
Hartomo Soewardi & Pakar Kursi Roda dari Universitas Islam Indonesia \\
Lobes Herdiman & Pakar Kursi Roda dari Universitas Sebelas Maret \\
\hline
\end{tabular}

Identifikasi kebutuhan stakeholder dilakukan dengan penyebaran kuesioner. Desain kuesioner kebutuhan standar kursi roda didapatkan dari berbagai literatur, dengan 3 dimensi utama sebagai parameter pengembangan standar, yaitu: (1) Performa Fungsional, (2) Dudukan dan Dukungan Postural, (3) Kekuatan, Daya Tahan dan Keamanan. Parameter yang didapatkan dari studi literatur ditunjukkan pada Tabel 2.

\subsection{Analisis Teknis}

Kebutuhan teknis diperoleh dengan cara mengintrepetasikan kebutuhan stakeholder dari kuesioner yang sudah direkapitulasi dan diolah menjadi aspek teknis menggunakan Zachman Framework. Zachman Framework merupakan metode analisis pada metode FACTS yang berguna untuk menstrukturisasi kebutuhan menggunakan pertanyaan dasar $5 \mathrm{~W}+1 \mathrm{H}$ yaitu What (Karakteristik apa yang dibutuhkan oleh stakeholder dalam pengembangan SNI kursi roda manual), Why (Mengapa pengukuran/ pengujian tersebut diperlukan), Who (Siapa yang melakukan pengukuran / pengujian tersebut), When (Kapan dilakukan pengukuran/pengujian), Where (Dimana pengukuran/ pengujian tersebut dilakukan) dan How (Bagaimana cara mendapatkan/menguji/ mengukur spesifikasi).

Analisis kebutuhan teknis juga digunakan untuk menstrukturisasi informasi yang diperoleh sehingga mencegah terjadinya duplikasi aspek teknis akibat informasi yang terlihat berbeda namun sebenarnya memiliki makna yang sama. Hasil analisis teknis di tujukkan pada Tabel 4.

Tabel 2 Desain Kuesioner

\begin{tabular}{|c|c|c|c|c|}
\hline Dimensi & Variabel & Atribut & Referensi & Kode \\
\hline \multirow{8}{*}{$\begin{array}{l}\text { Performa } \\
\text { Fungsional }\end{array}$} & \multirow{2}{*}{ Stabilitas } & Stabilitas Statis & Borg, dkk. (2007) & $\mathrm{A} 1$ \\
\hline & & Stabilitas Dinamis & Borg, dkk. (2007) & $\mathrm{A} 2$ \\
\hline & \multirow{2}{*}{$\begin{array}{l}\text { Transporting } \\
\text { wheechair }\end{array}$} & $\begin{array}{l}\text { Kemudahan berpindah dari \& ke kursi } \\
\text { roda }\end{array}$ & Borg, dkk. (2007) & A3 \\
\hline & & Kemudahan mengangkut kursi roda & Borg, dkk. (2007) & A4 \\
\hline & \multirow{2}{*}{$\begin{array}{l}\text { Kemampuan } \\
\text { Manuver }\end{array}$} & $\begin{array}{l}\text { Manuver di sekitar rintangan (ruang } \\
\text { terbatas) }\end{array}$ & Borg, dkk. (2007) & A5 \\
\hline & & Manuver melewati rintangan & Borg, dkk. (2007) & $\mathrm{A} 6$ \\
\hline & \multirow[b]{2}{*}{ Fungsi tambahan } & Efisiensi energi & Borg, dkk. (2007) & A7 \\
\hline & & $\begin{array}{l}\text { Kemudahan memperbaiki/memperoleh } \\
\text { komponen }\end{array}$ & Borg, dkk. (2007) & A8 \\
\hline \multirow{9}{*}{$\begin{array}{l}\text { Dudukan } \\
\text { dan } \\
\text { dukungan } \\
\text { postural }\end{array}$} & \multirow{9}{*}{ Dimensi } & Panjang Maksimum & ISO $7176-5$ & B1 \\
\hline & & Lebar & ISO 7176-5 & B2 \\
\hline & & Tinggi Total & ISO $7176-5$ & B3 \\
\hline & & Tinggi Kursi & ISO $7176-5$ & B4 \\
\hline & & Lebar Tempat Duduk & ISO 7176-5 & B5 \\
\hline & & Tinggi tempat duduk dari Tanah & ISO 7176-5 & B6 \\
\hline & & $\begin{array}{l}\text { Tinggi sandaran tangan dari tempat } \\
\text { duduk }\end{array}$ & ISO $7176-5$ & B7 \\
\hline & & Panjang tempat duduk & ISO 7176-5 & B8 \\
\hline & & Tinggi sandaran & ISO 7176-5 & B9 \\
\hline
\end{tabular}




\begin{tabular}{|c|c|c|c|c|}
\hline & & Berat maksimal kursi roda & ISO 7176-5 & $\mathrm{B} 10$ \\
\hline & & $\begin{array}{l}\text { Menyesuaikan antropometri masyarakat } \\
\text { Indonesia }\end{array}$ & Soewardi, H (2015) & B11 \\
\hline & & Tipe Kursi & Borg, dkk. (2007) & $\mathrm{B} 12$ \\
\hline & Dudukan & Bantalan kursi & Borg, dkk. (2007) & $\mathrm{B} 13$ \\
\hline & Dudukan & Bahan kursi & Borg, dkk. (2007) & B14 \\
\hline & & Bahan bantalan kursi & Borg, dkk. (2007) & B15 \\
\hline & & Sandaran punggung (beckrest) & ISO 7176-5 & B16 \\
\hline & & Pijakan kaki (footrest) & Borg, dkk. (2007) & B17 \\
\hline & Adjustable and & Sandaran tangan (armrest) & Borg, dkk. (2007) & B18 \\
\hline & & Roda belakang (Rear wheels) & Borg, dkk. (2007) & B19 \\
\hline & & Push Handle & Borg, dkk. (2007) & B20 \\
\hline & & Perakitan dengan pengelasan elektrik & Soewardi, (2015) & $\mathrm{C} 1$ \\
\hline & & Pijakan kaki kuat & Borg, dkk. (2007) & $\mathrm{C} 2$ \\
\hline & & Kuat dalam penggunaan normal & Borg, dkk. (2007) & $\mathrm{C} 3$ \\
\hline & Desain Kokoh & Kuat dalam penggunaan beban maksimal & Borg, dkk. (2007) & $\mathrm{C} 4$ \\
\hline & & Kursi roda tidak rusak saat jatuh & Borg, dkk. (2007) & $\mathrm{C} 5$ \\
\hline & & Tidak ada deformasi plastis permukaan & ISO 7176-8 (2014) & $\mathrm{C} 6$ \\
\hline & & Tidak ada keretakan komponen & ISO 7176-8 (2014) & $\mathrm{C} 7$ \\
\hline Kekuatan, & Material kuat & Material rangka keras & Soewardi, (2015) & $\mathrm{C} 8$ \\
\hline Daya & & Rangka kursi & Borg, dkk. (2007) & $\mathrm{C9}$ \\
\hline Tahan, dan & Ketahanan & Push Handle & Borg, dkk. (2007) & $\mathrm{C} 10$ \\
\hline & Flammahility & Tidak mudah terbakar & Borg, dkk. (2007) & $\mathrm{C} 11$ \\
\hline & ridmintavimy & Tahan Korosi & Mhatre, dkk (2017) & $\mathrm{C} 12$ \\
\hline & & Permukaan rata & Borg, dkk. (2007) & $\mathrm{C} 13$ \\
\hline & Keamanan & Cover ban & Kharisma. (2016) & C14 \\
\hline & & Memiliki stiker reflektif & Borg, dkk. (2007 & $\mathrm{C} 15$ \\
\hline & Kefektifan rem & Berhenti pada jalan turunan & Borg, dkk. (2007) & C16 \\
\hline & кетектітаn r & Tidak terlepas tiba-tiba & Borg, dkk. (2007) & $\mathrm{C} 17$ \\
\hline
\end{tabular}

Tabel 3 Rekapitulasi Kuesioner.

\begin{tabular}{lccc}
\hline Kode & $\begin{array}{c}\text { Persentase } \\
\text { Setuju }\end{array}$ & Kode & $\begin{array}{c}\text { Persentase } \\
\text { Setuju }\end{array}$ \\
\hline A1 & $97,3 \%$ & B15 & $89,2 \%$ \\
\hline A2 & $91,9 \%$ & B16 & $89,2 \%$ \\
\hline A3 & $89,2 \%$ & B17 & $91,9 \%$ \\
\hline A4 & $91,9 \%$ & B18 & $89,2 \%$ \\
\hline A5 & $91,9 \%$ & B19 & $91,9 \%$ \\
\hline A6 & $94,6 \%$ & B20 & $78,4 \%$ \\
\hline A7 & $94,6 \%$ & C1 & $81,1 \%$ \\
\hline A8 & $86,5 \%$ & C2 & $86,5 \%$ \\
\hline B1 & $94,6 \%$ & C3 & $94,6 \%$ \\
\hline B2 & $97,3 \%$ & C4 & $89,2 \%$ \\
\hline B3 & $97,3 \%$ & C5 & $91,9 \%$ \\
\hline B4 & $94,6 \%$ & C6 & $86,5 \%$ \\
\hline B5 & $97,3 \%$ & C7 & $89,2 \%$ \\
\hline B6 & $97,3 \%$ & C8 & $89,2 \%$ \\
\hline B7 & $97,3 \%$ & C9 & $97,3 \%$ \\
\hline B8 & $94,6 \%$ & C10 & $86,5 \%$ \\
\hline B9 & $94,6 \%$ & C11 & $91,9 \%$ \\
\hline B10 & $89,2 \%$ & C12 & $43,2 \%$ \\
\hline B11 & $94,6 \%$ & C13 & $67,6 \%$ \\
\hline B12 & $89,2 \%$ & C14 & $91,9 \%$ \\
\hline B13 & $81,1 \%$ & C15 & $89,2 \%$ \\
\hline & $94,6 \%$ & C16 & $97,3 \%$ \\
\hline & & C17 & $97,3 \%$ \\
\hline
\end{tabular}

\subsection{Perbandingan Standar}

Perbandingan standar dilakukan dengan membandingkan standar acuan yang memuat pengujian pada dengan kebutuhan teknis stakeholder. Hal ini bertujuan untuk mengetahui gap dan overlap antara standar acuan dengan kebutuhan teknis. Perbandingan standar dilakukan melalui pendekatan informal, tipologi, dan aplikasi kasus. Standar yang dibandingkan adalah standar nasional dan internasional yang terkait dengan kursi roda. Melalui perbandingan standar kemudian diketahui standar apa yang memenuhi kebutuhan atau aspek teknis. Hasil perbandingan standar di tujukkan pada Tabel 4.

Tabel 4 Ringkasan Aspek Teknis dan Perbandingan Standar.

\begin{tabular}{lll}
\multicolumn{1}{c}{ Aspek Teknis } & $\begin{array}{c}\text { ISO 7176 } \\
\text { Series }\end{array}$ & $\begin{array}{l}\text { SNI 09-4663- } \\
\mathbf{1 9 9 8}\end{array}$ \\
\hline $\begin{array}{l}\text { Kursi roda stabil } \\
\text { saat menghadapi } \\
\text { tanjakan }\end{array}$ & ISO 7176-1 & $\begin{array}{l}\text { Tidak } \\
\text { Tersedia }\end{array}$ \\
\hline $\begin{array}{l}\text { Kursi roda stabil } \\
\text { saat menghadapi } \\
\text { turunan }\end{array}$ & ISO 7176-1 & $\begin{array}{l}\text { Tidak } \\
\text { Tersedia }\end{array}$ \\
\hline $\begin{array}{l}\text { Kursi roda stabil } \\
\text { pada } \text { posisi } \\
\text { menyamping } \\
\text { pada tanjakan }\end{array}$ & ISO 7176-1 & Tidak \\
\hline $\begin{array}{l}\text { Komponen } \\
\text { mudah diperoleh } \\
\text { dan diperbaiki }\end{array}$ & Tersedia & Tersedia \\
\hline Lebar pivot & ISO 7176-5 & Tidak \\
\hline \multicolumn{1}{c}{ U-Turn } & ISO 7176-5 & Tidak \\
\hline Lebar
\end{tabular}




\begin{tabular}{|c|c|c|c|c|c|}
\hline Aspek Teknis & $\begin{array}{c}\text { ISO } 7176 \\
\text { Series }\end{array}$ & $\begin{array}{c}\text { SNI 09-4663- } \\
1998\end{array}$ & Aspek Teknis & $\begin{array}{c}\text { ISO } 7176 \\
\text { Series }\end{array}$ & $\begin{array}{c}\text { SNI 09-4663- } \\
1998\end{array}$ \\
\hline $\begin{array}{l}\text { dalam ruang } \\
\text { yang terbatasi } \\
\text { oleh dinding }\end{array}$ & & Tersedia & $\begin{array}{l}\text { Lokasi depan } \\
\text { struktur } \\
\text { sandaran tangan }\end{array}$ & ISO 7176-7 & $\begin{array}{l}\text { Tidak } \\
\text { Tersedia }\end{array}$ \\
\hline \multirow{2}{*}{$\begin{array}{l}\text { Diameter } \\
\text { lingkaran putar / } \\
\text { rotasi }\end{array}$} & \multirow[t]{2}{*}{ ISO 7176-5 } & \multirow[t]{2}{*}{$\begin{array}{l}\text { Tidak } \\
\text { Tersedia }\end{array}$} & $\begin{array}{l}\text { Diameter } \\
\text { handrim }\end{array}$ & ISO 7176-7 & $\begin{array}{l}\text { Tidak } \\
\text { Tersedia }\end{array}$ \\
\hline & & & Diameter & ISO 7176-7 & Tidak \\
\hline \multirow{3}{*}{$\begin{array}{l}\text { Lebar yang } \\
\text { dibutuhkan untuk } \\
\text { koridor yang } \\
\text { berkemiringan }\end{array}$} & \multirow[t]{3}{*}{ ISO 7176-5 } & \multirow{3}{*}{$\begin{array}{l}\text { Tidak } \\
\text { Tersedia }\end{array}$} & penggerak & & Tersedia \\
\hline & & & $\begin{array}{l}\text { Jarak horizontal } \\
\text { poros roda }\end{array}$ & ISO 7176-7 & $\begin{array}{l}\text { Tidak } \\
\text { Tersedia }\end{array}$ \\
\hline & & & Jarak vertikal & ISO 7176-7 & Tidak \\
\hline \multirow{2}{*}{$\begin{array}{l}\text { Kedalaman } \\
\text { bidang pintu } \\
\text { masuk }\end{array}$} & \multirow[t]{2}{*}{ ISO 7176-5 } & \multirow{2}{*}{$\begin{array}{l}\text { Tidak } \\
\text { Tersedia }\end{array}$} & poros roda & & Tersedia \\
\hline & & & $\begin{array}{l}\text { Panjang } \\
\text { keseluruhan }\end{array}$ & ISO 7176-5 & $\begin{array}{l}\text { Tidak } \\
\text { Tersedia }\end{array}$ \\
\hline \multirow{3}{*}{$\begin{array}{l}\text { Lebar } \quad \text { koridor } \\
\text { yang dibutuhkan } \\
\text { untuk membuka } \\
\text { pintu pada posisi } \\
\text { kuri roda } \\
\text { menyamping }\end{array}$} & \multirow[t]{3}{*}{ ISO $7176-5$} & \multirow[t]{3}{*}{$\begin{array}{l}\text { Tidak } \\
\text { Tersedia }\end{array}$} & $\begin{array}{l}\text { Lebar } \\
\text { Keseluruhan }\end{array}$ & ISO 7176-5 & $\begin{array}{l}\text { Tidak } \\
\text { Tersedia }\end{array}$ \\
\hline & & & $\begin{array}{l}\text { Panjang } \\
\text { minimum kursi } \\
\text { roda saat terlipat }\end{array}$ & ISO 7176-5 & $\begin{array}{l}\text { Tidak } \\
\text { Tersedia }\end{array}$ \\
\hline & & & Lebar & ISO 7176-5 & Tidak \\
\hline $\begin{array}{l}\text { Ketinggian dari } \\
\text { lantai }\end{array}$ & ISO 7176-5 & $\begin{array}{l}\text { Tidak } \\
\text { Tersedia }\end{array}$ & $\begin{array}{l}\text { keseluruhan } \\
\text { minimum kursi }\end{array}$ & & Tersedia \\
\hline \multirow{2}{*}{$\begin{array}{l}\text { Sudut } \\
\text { kursi }\end{array}$} & \multirow[t]{2}{*}{ ISO 7176-7 } & \multirow{2}{*}{$\begin{array}{l}\text { Tidak } \\
\text { Tersedia }\end{array}$} & roda saat terlipat & & \\
\hline & & & Ketinggian & ISO $7176-5$ & Tidak \\
\hline $\begin{array}{l}\text { Kedalaman kursi } \\
\text { efektif }\end{array}$ & ISO $7176-7$ & $\begin{array}{l}\text { Tidak } \\
\text { Tersedia }\end{array}$ & $\begin{array}{l}\text { keseluruhan } \\
\text { minimum saat }\end{array}$ & & Tersedia \\
\hline Lebar kursi & ISO 7176-7 & $\begin{array}{l}\text { Tidak } \\
\text { Tersedia }\end{array}$ & $\begin{array}{l}\text { kursi } \quad \text { roda } \\
\text { terlipat }\end{array}$ & & \\
\hline $\begin{array}{l}\text { Lebar } \quad \text { kursi } \\
\text { efektif }\end{array}$ & ISO 7176-7 & $\begin{array}{l}\text { Tidak } \\
\text { Tersedia }\end{array}$ & $\begin{array}{l}\text { Massa dari } \\
\text { komponen }\end{array}$ & ISO $7176-5$ & $\begin{array}{l}\text { Tidak } \\
\text { Tersedia }\end{array}$ \\
\hline \multirow{2}{*}{$\begin{array}{l}\text { Tinggi } \\
\text { permukaan kursi } \\
\text { depan }\end{array}$} & \multirow[t]{2}{*}{ ISO 7176-7 } & Tidak & terberat & & \\
\hline & & Tersedia & Tinggi Handgrip & ISO 7176-5 & $\begin{array}{l}\text { Tidak } \\
\text { Tersedia }\end{array}$ \\
\hline Sudut sandaran & ISO 7176-7 & $\begin{array}{l}\text { Tidak } \\
\text { Tersedia }\end{array}$ & Total masa & ISO $7176-5$ & $\begin{array}{l}\text { Tidak } \\
\text { Tersedia }\end{array}$ \\
\hline Lebar sandaran & ISO 7176-7 & $\begin{array}{l}\text { Tidak } \\
\text { Tersedia }\end{array}$ & $\begin{array}{l}\text { Bahan Bantalan } \\
\text { Kursi }\end{array}$ & $\begin{array}{l}\text { Tidak } \\
\text { Tersedia }\end{array}$ & $\begin{array}{l}\text { Tidak } \\
\text { Tersedia }\end{array}$ \\
\hline $\begin{array}{lr}\text { Jarak } & \text { headrest } \\
\text { dari } & \text { depan }\end{array}$ & ISO 7176-7 & $\begin{array}{l}\text { Tidak } \\
\text { Tersedia }\end{array}$ & $\begin{array}{ll}\text { Tipe } & \text { kursi } \\
\text { (dudukan) }\end{array}$ & $\begin{array}{l}\text { Tidak } \\
\text { Tersedia }\end{array}$ & $\begin{array}{l}\text { Tidak } \\
\text { Tersedia }\end{array}$ \\
\hline sandaran & & & Rem Parkir & ISO $7176-3$ & Tidak \\
\hline Tinggi headrest & ISO 7176-7 & Tidak & & & Tersedia \\
\hline $\begin{array}{l}\text { dari atas } \\
\text { dudukan }\end{array}$ & & Tersedia & $\begin{array}{lr}\text { Rem raat } \\
\text { Berjalan, operasi }\end{array}$ & ISO 7176-3 & $\begin{array}{l}\text { Tidak } \\
\text { Tersedia }\end{array}$ \\
\hline Jarak pijakan & ISO 7176-7 & Tidak & normal & & \\
\hline kaki ke dudukan & & Tersedia & Rem saat & ISO 7176-3 & Tidak \\
\hline $\begin{array}{l}\text { Tinggi pijakan } \\
\text { kaki }\end{array}$ & ISO 7176-7 & $\begin{array}{l}\text { Tidak } \\
\text { Tersedia }\end{array}$ & $\begin{array}{l}\text { Berjalan, operasi } \\
\text { dengan perintah }\end{array}$ & & Tersedia \\
\hline Panjang pijakan & ISO 7176-7 & Tidak & balik & & \\
\hline kaki & & Tersedia & Rem saat & ISO 7176-3 & Tidak \\
\hline $\begin{array}{l}\text { Sudut pijakan } \\
\text { kaki }\end{array}$ & ISO 7176-7 & $\begin{array}{l}\text { Tidak } \\
\text { Tersedia }\end{array}$ & $\begin{array}{l}\text { Berjalan, operasi } \\
\text { darurat }\end{array}$ & & Tersedia \\
\hline $\begin{array}{l}\text { Sudut kaki ke } \\
\text { dudukan }\end{array}$ & ISO 7176-7 & $\begin{array}{l}\text { Tidak } \\
\text { Tersedia }\end{array}$ & $\begin{array}{l}\text { Pengujian } \\
\text { horizontal }\end{array}$ & $\begin{array}{l}\text { ISO 7176- } \\
16\end{array}$ & $\begin{array}{l}\text { Tidak } \\
\text { Tersedia }\end{array}$ \\
\hline Ketinggian & ISO 7176-7 & Tidak & ketahanan api & & \\
\hline sandaran tangan & & Tersedia & Pengujian & ISO 7176- & Tidak \\
\hline $\begin{array}{l}\text { Sandaran tangan } \\
\text { ke sandaran }\end{array}$ & ISO 7176-7 & $\begin{array}{l}\text { Tidak } \\
\text { Tersedia }\end{array}$ & $\begin{array}{l}\text { vertikal } \\
\text { ketahanan api }\end{array}$ & 16 & Tersedia \\
\hline Panjang armrest & ISO 7176-7 & $\begin{array}{l}\text { Tidak } \\
\text { Tersedia }\end{array}$ & Ketahanan korosi & $\begin{array}{l}\text { Tidak } \\
\text { Tersedia }\end{array}$ & $\begin{array}{l}\text { Tidak } \\
\text { Tersedia }\end{array}$ \\
\hline $\begin{array}{l}\text { Lebar sandaran } \\
\text { tangan }\end{array}$ & ISO 7176-7 & $\begin{array}{l}\text { Tidak } \\
\text { Tersedia }\end{array}$ & $\begin{array}{l}\text { Dukungan } \\
\text { Lengan: Daya }\end{array}$ & ISO 7176-8 & $\begin{array}{l}\text { Tidak } \\
\text { Tersedia }\end{array}$ \\
\hline $\begin{array}{l}\text { Sudut sandaran } \\
\text { tangan }\end{array}$ & ISO 7176-7 & $\begin{array}{l}\text { Tidak } \\
\text { Tersedia }\end{array}$ & $\begin{array}{l}\text { tahan terhadap } \\
\text { gaya kebawah }\end{array}$ & & \\
\hline $\begin{array}{l}\text { Jarak antara } \\
\text { lengan kursi }\end{array}$ & ISO 7176-7 & $\begin{array}{l}\text { Tidak } \\
\text { Tersedia }\end{array}$ & $\begin{array}{l}\begin{array}{l}\text { Dukungan } \\
\text { Kaki: } \\
\text { Daya }\end{array} \\
\text { tahan }\end{array}$ & ISO 7176-8 & $\begin{array}{l}\text { Tidak } \\
\text { Tersedia }\end{array}$ \\
\hline
\end{tabular}




\begin{tabular}{|c|c|c|}
\hline Aspek Teknis & $\begin{array}{l}\text { ISO } 7176 \\
\text { Series }\end{array}$ & $\begin{array}{c}\text { SNI 09-4663- } \\
1998\end{array}$ \\
\hline $\begin{array}{l}\text { terhadap gaya } \\
\text { kebawah }\end{array}$ & & \\
\hline $\begin{array}{l}\text { Pengujian tipping } \\
\text { levers }\end{array}$ & ISO $7176-8$ & $\begin{array}{l}\text { Tidak } \\
\text { Tersedia }\end{array}$ \\
\hline $\begin{array}{l}\text { Pengujian } \\
\text { Handgrip }\end{array}$ & ISO 7176-8 & $\begin{array}{l}\text { Tidak } \\
\text { Tersedia }\end{array}$ \\
\hline $\begin{array}{l}\text { Dukungan } \\
\text { Lengan: Daya } \\
\text { tahan terhadap } \\
\text { gaya keatas }\end{array}$ & ISO 7176-8 & $\begin{array}{l}\text { Tidak } \\
\text { Tersedia }\end{array}$ \\
\hline $\begin{array}{lr}\text { Dukungan } & \text { Kaki: } \\
\text { Daya } & \text { tahan } \\
\text { terhadap } & \text { gaya } \\
\text { keatas } & \\
\end{array}$ & ISO 7176-8 & $\begin{array}{l}\text { Tidak } \\
\text { Tersedia }\end{array}$ \\
\hline $\begin{array}{lr}\text { Push } & \text { Handle: } \\
\text { Daya } & \text { tahan } \\
\text { terhadap } & \text { beban } \\
\text { keatas } & \\
\end{array}$ & ISO $7176-8$ & $\begin{array}{l}\text { Tidak } \\
\text { Tersedia }\end{array}$ \\
\hline $\begin{array}{l}\text { Dukungan } \\
\text { Punggung }\end{array}$ & ISO $7176-8$ & $\begin{array}{l}\text { Tidak } \\
\text { Tersedia }\end{array}$ \\
\hline Handrim & ISO 7176-8 & $\begin{array}{l}\text { Tidak } \\
\text { Tersedia }\end{array}$ \\
\hline Castor & ISO $7176-8$ & $\begin{array}{l}\text { Tidak } \\
\text { Tersedia }\end{array}$ \\
\hline Dukungan Kaki & ISO 7176-8 & $\begin{array}{l}\text { Tidak } \\
\text { Tersedia }\end{array}$ \\
\hline Anti-tip Device & ISO 7176-8 & $\begin{array}{l}\text { Tidak } \\
\text { Tersedia }\end{array}$ \\
\hline Multi-drum test & ISO 7176-8 & $\begin{array}{l}\text { Tidak } \\
\text { Tersedia }\end{array}$ \\
\hline $\begin{array}{l}\text { Drop Test } \\
\text { Jatuh) }\end{array}$ & ISO 7176-8 & $\begin{array}{l}\text { Tersedia } \\
(8.4)\end{array}$ \\
\hline $\begin{array}{l}\text { Pengujian } \\
\text { Fatigue untuk } \\
\text { rem parkir }\end{array}$ & ISO $7176-8$ & $\begin{array}{l}\text { Tidak } \\
\text { Tersedia }\end{array}$ \\
\hline
\end{tabular}

Setelah dilakukan perbandingan standar dapat dibentuk kerangka RSNI untuk kursi roda manual. Kerangka RSNI ditunjukkan pada Gambar 4. Terdapat 8 parameter utama sebagai usulan untuk standar kursi roda manual yaitu stabilitas stastis, kemampuan manuver, dimensi, keefektifan rem, ketahanan pengapian, kekuatan statis, kekuatan impact, dan kekuatan fatigue. Indikator dalam parameter standar dihasilkan dari aspek teknis yang telah memiliki standar pengujian.

\subsection{Pengujian Standar}

Pengujian digunakan untuk menguji apakah kerangka standar yang dirumuskan dapat diterima melalui konsensus. Dalam tahap ini kerangka standar yang ditetapkan akan diverifikasi dan divalidasi.

$$
\text { Verifikasi dilakukan dengan }
$$
menggunakan SEM. Metode pendekatan SEM yang dipilih adalah PLS-SEM (Partial Least Square- Structural Equation Model). PLS merupakan metode analisis yang powerful karena dapat diterapkan pada semua skala data, tidak membutuhkan banyak asumsi dan ukuran sampel tidak harus besar. PLS selain dapat digunakan sebagai konfirmasi teori juga dapat digunakan untuk membangun hubungan yang belum ada landasan teorinya atau untuk pengujian proposisi. PLS juga dapat digunakan untuk pemodelan struktural dengan indikator bersifat reflektif ataupun formatif (Jaya dkk, 2008). Perhitungan PLS-SEM dilakukan dengan menggunakan software Smart-PLS. Perhitungan SEM pada artikel ini berguna untuk mengetahui bagaimana pengaruh indikator-indikator kebutuhan stakeholder yang telah dibentuk dalam kerangka RSNI terhadap tujuan standarisasi. Tujuan standardisasi yang digunakan merupakan tujuan menurut UU No.20

Tahun 2014, yaitu: melindungi konsumen, melindungi produsen, dan meningkatkan daya saing. Kerangka model SEM ditunjukkan pada Gambar 5.

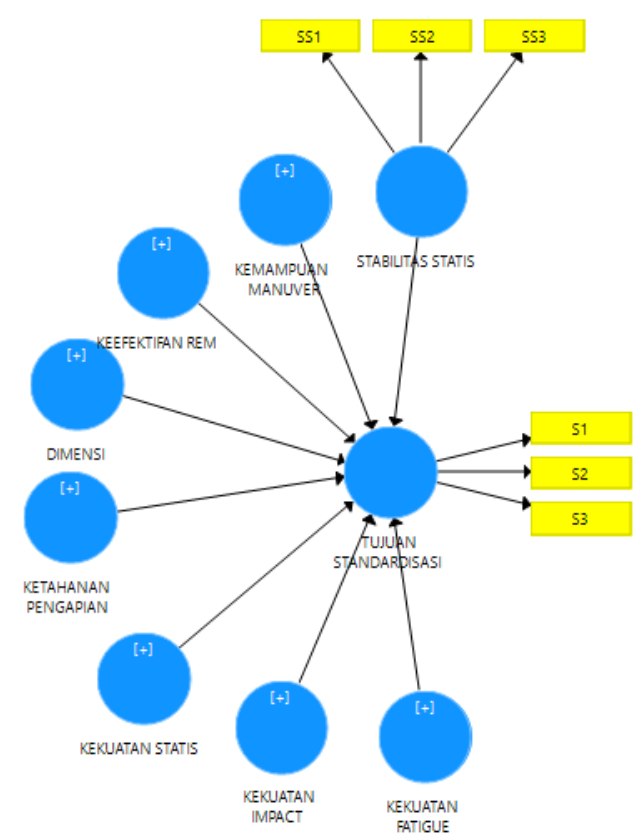

Gambar 5 Kerangka Structural Equation Model.

Berikut model pengukuran untuk kerangka Structural Equation Model. Model berikut meruapakan contoh model untuk pengukuran variabel stabilitas statis.

$$
\begin{aligned}
& x_{4}=A_{x} \xi_{1}+\delta_{1} \\
& x_{q}=A_{x q} \xi_{1}+\delta_{g} \\
& x_{i}=A_{x} \xi_{1}+\delta_{y}
\end{aligned}
$$

Berikut model struktural untuk kerangka Structural Equation Model.

$\eta_{6}=\gamma_{4} \bar{\delta}_{6}+\cdots+\gamma_{4} \bar{F}_{8}+\xi_{3}$ 


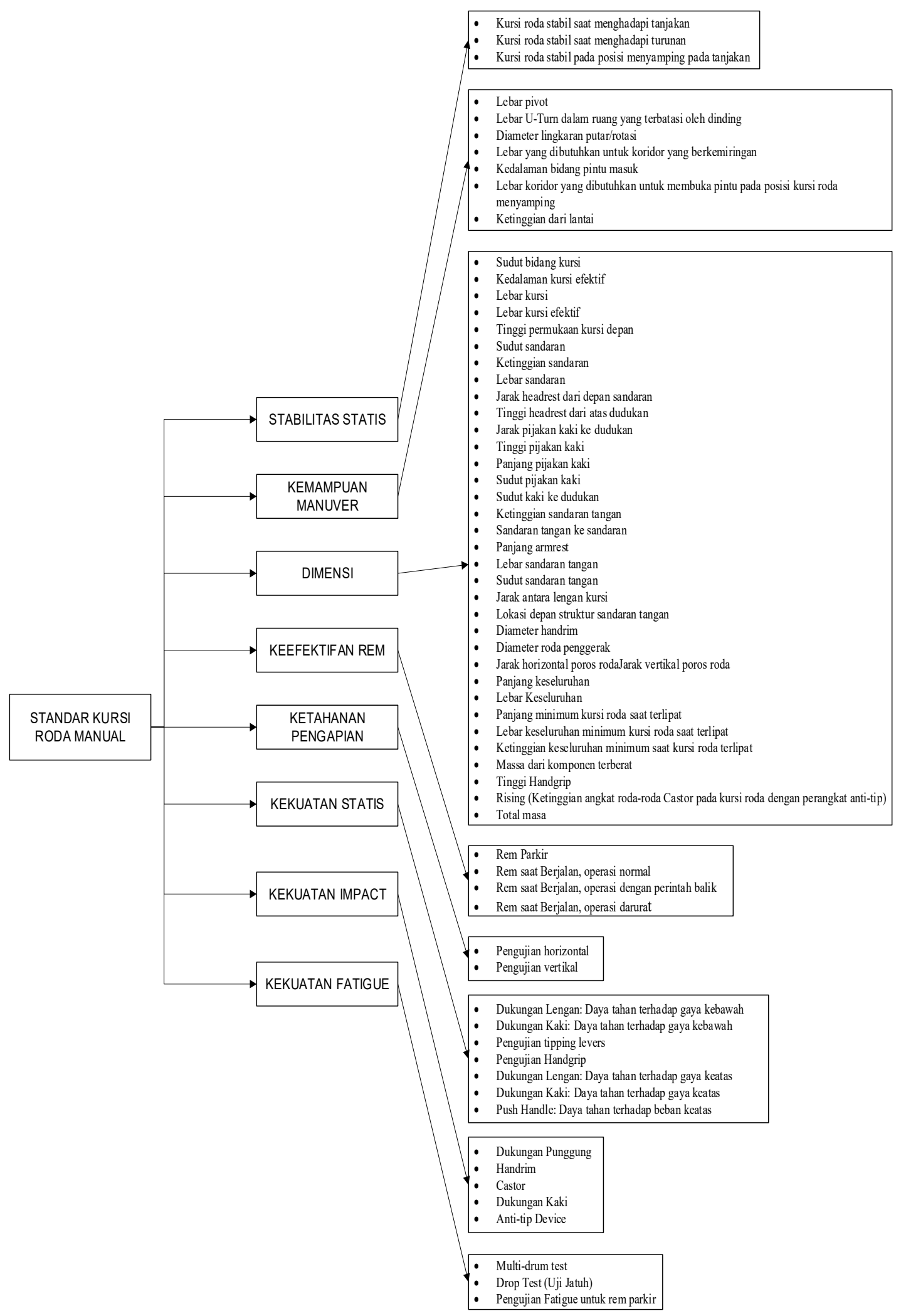

Gambar 4 Kerangka RSNI.

- Pengujian Fatigue untuk rem parkir

Kerangka Structural Equation Model ini

memverifikasi aspek rancangan standar mana diusulkan sebagai kerangka untuk yang memiliki pengaruh signifikan terhadap 
tercapainya tujuan standar. Sehingga standar yang diatur benar-benar memiliki pengaruh untuk mencapai tujuan standardisasi. Setelah itu dilakukan validasi melalui Focus Group Discussion untuk stakeholder yang terkait.

\section{KESIMPULAN}

Pada artikel ini telah diberikan parameter untuk kerangka kerja Standar Nasional Indonesia kursi roda manual serta kerangka proses verifikasinya. Terdapat 8 parameter utama sebagai usulan untuk standar kursi roda manual yaitu stabilitas statis, kemampuan manuver, dimensi, keefektifan rem, ketahanan pengapian, kekuatan statis, kekuatan impact, dan kekuatan fatigue. Proses verifikasi dengan menggunakan SEM digunakan untuk mengetahui parameter mana saja yang memilikii pengaruh signifikan terhadap tujuan standardisasi, sehingga diharapkan dapat menjadi acuan dalam penyusunan SNI kursi roda manual.

\section{UCAPAN TERIMA KASIH}

Artikel ini merupakan bagian dari luaran penelitian hasil kerja sama antara UNS dengan BSN dengan No. 259/UN27/HK/2018. Ucapan terima kasih disampaikan kepada LPPM UNS dan Pusat Penelitian dan Pengembangan Standardisasi, Badan Standardisasi Nasional, serta semua pihak yang mendukung penelitian ini.

\section{DAFTAR PUSTAKA}

Batan, I. M. L. (2006). Pengembangan Kursi Roda Sebagai Upaya Peningkatan Ruang Gerak Penderita Cacat Kaki. Jurnal Teknik Industri, 8(2), 97-105. Retrieved from

http://puslit2.petra.ac.id/ejournal/index.ph p/ind/article/view/16549

Borg, J \& Khasnabis, C. (2008). Guidelines on the provision of manual wheelchairs in less-resourced settings. World Health Organization.

Cook, Albert M. (2015). Assistive Technologies: Principles and Practice, 4th ed. Elsevier.

Direktorat Jenderal Bina Kefarmasian Dan Alat Kesehatan. (2015). Rencana Aksi Kegiatan Tahun 2015 - 2019 Direktorat Bina Produksi Dan Distribusi Alat Kesehatan. Jakarta: Kemenkes RI.
International Organization for Standardization. (2014). ISO 7176-1 Wheelchairs: Determination of static stability. ISO

International Organization for Standardization. (2012). ISO 7176-3 Wheelchairs: Determining the effectiveness of the brakes. ISO

International Organization for Standardization. (2008). ISO 7176-5 Wheelchairs: Determination of dimensional space, mass and maneuverability. ISO

International Organization for Standardization. (1998). ISO 7176-7 Wheelchairs: Measurements of seating and wheel dimensions. ISO

International Organization for Standardization. (2014). ISO 7176-8 Wheelchairs: Requirements and test methods for static strength, impact and fatigue. ISO

International Organization for Standardization. (2012). ISO 7176-16 Wheelchairs: Resistance to ignition of postural support devices. ISO

Jaya, I. G. N. M. \& Sumertajaya, I. M. (2008). Pemodelan Persamaan Strutural dengan Partial Least Square. Semnas Matematika dan Pendidikan Matematika

Kemenperin_PPI 2016 Unjuk Produk Unggul Industri Alsintan dan Alkes. (2016). Retrieved July 30, 2018, from http://www.kemenperin.go.id/artikel/1633 8/PPI-2016-Unjuk-Produk-UnggulIndustri-Alsintan-dan-Alkes

Kharisma, Atminati. (2016). Desain Kursi Roda dengan Sistem Kemudi Tuas sebagai Sarana Mobilitas bagi Anak Penderita Cerebral Palsy Usia 6 hingga 10th. JURNAL SAINS DAN SENI ITS Vol. 5, No.2, (2016) 2337-3520 (2301-928X Print).

Kleynen, M., Braun, S. M., Bleijlevens, M. H., Lexis, M. A., Rasquin, S. M., Halfens, J., ... Masters, R. S. W. (2014). Using a Delphi technique to seek consensus regarding definitions, descriptions and classification of terms related to implicit and explicit forms of motor learning. PLoS ONE, 9(6), 1-11. https://doi.org/10.1371/journal.pone.0100 227

Nurwullan, E., \& Tinaprilla, N. (2015). Aplikasi Partial Least Square Dalam Pengujian Implikasi Jaringan Kerjasama Dan Inovasi Usaha Mikro Kecil Pengolahan Kedelai. Informatika Pertanian, Vol. 24 No 2, 205-214. 
Peraturan Pemerintah (PP) No. 102 Tahun 2012 mengenai Standardisasi Nasional

Prianjani, D., Fahma, F., Sutopo, W., Nizam, M., Purwanto, A., Louhenapessy, B. B., \& Mulyono, A. B. (2017). The standard development for the National Standard of Indonesian (SNI) of the cell traction battery Lithium-ion Ferro phospate secondarry for electric vehicles applications. 2016 2nd International Conference of Industrial, Mechanical, Electrical, and Chemical Engineering, ICIMECE 2016, 213-218. https://doi.org/10.1109/ICIMECE.2016.79 10460

Rahmawatie, B., Sutopo, W., Fahma, F., Purwanto, A., Nizam, M., Louhenapessy, B. B., \& Mulyono, A. B. (2017). Designing framework for standardization and testing requirements of battery management system for electric vehicle application. 2017 4th International Conference on Electric Vehicular Technology (ICEVT), 7-12. https://doi.org/10.1109/ICEVT.2017.8323 525

Santoso, Singgih. (2015). Menguasai Statistik Multivariat. Jakarta: PT Elex Media Komputindo.

Soewardi, Hartomo. (2015). Inovative Design of Wheelchair by Using User Centered
Design Approach. Proceeding 8th International Seminar on Industrial Engineering and Management.

Sutopo, W., \& Kadir, E. A. (2018). Designing Framework for Standardization Case Study: Lithium-lon Battery Module in Electric Vehicle Application, 8(1), 220226.

https://doi.org/10.11591/ijece.v8i1.pp220 $-226$

Ulum, M., Tirta, I. M., \& Anggraeni, D. (2014). Analisis Structural Equation Modeling (SEM) Untuk Sampel Kecil Dengan Pendekatan Partial Least Square (PLS). Prosiding Seminar Nasional Matematika Universitas Jember, (November), 1-15.

Undang Undang (UU) No.20 Tahun 2014 tentang Standardisasi dan Penilaian Kesesuaian

Whidiarso, wahyu. (2010). Pengembangan Skala Psikologi: Lima Kategori Respons ataukah Empat Kategori Respons?. diakses online dari ugm.ac.id/files/widhiarso_2010_respon _alternatif_tengah_pada_skala_likert.pdf

Witherell, Paul; Rachuri, Sudarsan; Narayanan, Anantha dan Hyun Lee, Jae. (2013). FACTS: A Framework for Analysis, Comparison, and Testing of Standards. National Institute of Standards and Technology, United States 